\title{
Effect of bone meal on the utilization of iron by anaemic rats
}

\author{
By D. G. CHAPMAN AND J. A. CAMPBELL \\ Food and Drug Laboratories, Department of National Health and Welfare, \\ Ottawa, Canada
}

(Received 3I Fuly 1956-Revised I4 Fanuary 1957)

The introduction into Canada in 1953 of enriched flour, which may contain added bone meal or calcium carbonate as an optional ingredient, raised the question of the possible effect of these materials on the utilization of iron as reflected by haemoglobin levels and liver iron storage in anaemic rats.

The reports in the literature about the effect of calcium and phosphorus on the utilization of iron are conflicting. Earlier workers, including von Wendt (1905), Sherman (1907) and Davidson, Fullerton, Howie, Croll, Orr \& Godden (1933), working with human subjects, and Orten, Smith \& Mendel (1936) and Day \& Stein (1938), using rats, showed that additional calcium in the diet tended to promote the utilization of iron. Hegsted, Finch \& Kinney (1949) reported that, under the conditions of their experiments, the addition of calcium carbonate appeared to have no effect on the accumulation of liver iron in rats. Widdowson \& McCance ( 1942) stated that calcium added to either white or brown bread 'certainly did not interfere with iron absorption' in the human adult. On the other hand, Kletzien (1940), Anderson, McDonough \& Elvehjem (I940) and Freeman \& Ivy (I942) reported that calcium retards iron utilization in rats. More recently, Greig (1952) showed that weanlings born of white Swiss mice on diets containing $2 \%$ added calcium carbonate were anaemic relative to the offspring from mice given a control diet. Pett (I952) reported that bone meal in enriched flour led to anaemia in children. Since this work was carried out, Gubler (1956) has reported that 'calcium in moderate amounts can have a favorable effect on iron absorption by combining with the phosphate ions. On the other hand, if excessive amounts of calcium are present in the diet, the absorption of iron is inhibited, which gives rise to an iron-deficiency anemia.'

As to the effect of phosphorus on iron assimilation, Hegsted et al. (1949) showed that iron absorption could be reduced by the addition of phosphates to the diet. Day 8 Stein (1938) found that an excess of phosphorus in a low-mineral ration led to anaemia in rats. Perosa \& Raccuglia (I95 $\mathrm{r}$ ) have found that in four human subjects the presence of $\mathrm{K}_{2} \mathrm{HPO}_{4}$ caused decreased iron absorption as a result of the formation of an insoluble iron phosphate. On the other hand, Anderson et al. (I940) concluded that, under the conditions of their experiments, phosphorus had a stimulating effect on the absorption of iron. Dell'Aquila \& Bini (1953), working with human subjects, concluded that calcium salts improve the rate of iron assimilation, whereas phosphates have an adverse effect. 
The conflicting reports in the literature about the effect of calcium and phosphorus on the utilization of iron, together with the fact that most results previously reported are not directly applicable to our problem, suggested the need for its further study. It is the purpose of the present paper to report the results of experiments demonstrating the effect that the addition of bone meal to flour had on the utilization of iron by anaemic rats.

\section{EXPERIMENTAL}

Plan of experiment. This work was carried out in two experiments designed to determine the effect that the addition of edible bone meal to unenriched flour might have on the utilization of iron, as reflected by haemoglobin levels, liver iron storage, heart weights and gains in body-weight of anaemic rats. Three levels of bone meal were used in Exps. I and 2, namely $0,1 \cdot 5$ or $7 \cdot 5 \mathrm{~g} / \mathrm{lb}$. flour. The $\mathrm{I} \cdot 5 \mathrm{~g}$ level would supply approximately $500 \mathrm{mg}$ calcium/lb. flour. ${ }^{*}$ Three levels of iron were also used. In Exp. 1, o, 10 or $20 \mathrm{mg}$ anhydrous $\mathrm{FeSO}_{4}$ were added per lb. flour, and in Exp. 2, 0,4 of or $200 \mathrm{mg} / \mathrm{lb}$. flour.

Diets. The diets fed to the rats consisted of $80 \%$ dried bread and $20 \%$ basal ration. Where the diets were to contain added bone meal or ferrous sulphate, these ingredients were incorporated into the flour before baking. The composition of the diet is shown in Table $\mathrm{x}$. All bread used in these studies was baked in our laboratories,

Table I. Composition of diets

\begin{tabular}{l}
\multicolumn{2}{l}{$\begin{array}{l}\text { Constituents } \\
\text { Bread, dried* (\%) }\end{array}$} \\
Basal ration (\%) \\
Casein (\%) \\
Salts, U.S.P. XIV† (\%) \\
Maize oil $(\%)$ \\
Alphacel $(\%)$
\end{tabular}

\begin{tabular}{|c|c|}
\hline \multicolumn{2}{|l|}{ Vitamins } \\
\hline Thiamine ( $\mathrm{mg} / \mathrm{l}$ oo $\mathrm{g}$ diet) & 0.5 \\
\hline Riboflavin (mg/roo g diet) & $1 \cdot 0$ \\
\hline Calcium D-pantothenate ( $\mathrm{mg} / \mathrm{r} 00 \mathrm{~g}$ diet) & $2 \cdot 0$ \\
\hline Pyridoxine (mg/100 g diet) & 0.5 \\
\hline Nicotinamide (mg/roo g diet) & $2 \cdot 0$ \\
\hline Folic acid (mg/loo g diet) & 0.2 \\
\hline$p$-Aminobenzoic acid (mg/roo g diet) & $I \cdot 0$ \\
\hline Vitamin $B_{12}(\mathrm{mg} /$ /oo $\mathrm{g}$ diet $)$ & 0.0 \\
\hline Inositol (mg/loo g diet) & $20 \cdot 0$ \\
\hline Choline ( $\mathrm{mg} /$ Ioo $\mathrm{g}$ diet) & $100 \cdot 0$ \\
\hline Vitamin Af (i.u./week) & 200 \\
\hline Vitamin $\mathrm{D}+$ (i.u./week) & 40 \\
\hline Vitamin Ef (i.u./week) & 5 \\
\hline
\end{tabular}

* The iron or bone meal added to some of the diets was incorporated into the flour before baking the bread.

+ Calcium diphosphate, dibasic potassium phosphate and ferric ammonium citrate were replaced by Alphacel (see footnote to p. $1+9$ ).

$\ddagger$ Given orally by means of a syringe.

air-dried and finely ground. The ingredients used in preparing the bread were flour, distilled water, dehydrated yeast, sodium chloride, sugar and shortening. Unenriched flour (from one lot of wheat), to which varying amounts of bone meal and iron were added, was used in baking the bread. The salt mixture incorporated into the diet was that described in U.S.P. XIv (Pharmacopoeia of the United States of America, Fourteenth

* If calcium is added to enriched flour in Canada, it must be present in an amount of from 500 to $650 \mathrm{mg} / \mathrm{lb}$.

+ Forty mg $\mathrm{FeSO}_{4}$ would contribute the amount of iron that may be present in enriched flour, i,e. I $3.0-16.5 \mathrm{mg} / \mathrm{lb}$. 
Revision, 1950) for the biological assay of vitamin A. In order to keep the phosphorus and iron content of the salt mixture to a minimum, calcium diphosphate, dibasic potassium phosphate and ferric ammonium citrate were replaced by Alphacel*. The rats were fed $a d l i b$., and a weekly record was kept of the food consumption. Distilled water was provided for all rats. Aluminium or painted food dishes were used to reduce iron contamination. Each lot of the various diets was assayed for iron, calcium and phosphorus.

Cages. The rats were housed in individual stainless steel cages.

Haemoglobin. The method of Rimington (r942) was used for the haemoglobin determinations. A standard curve was prepared by means of crystalline haemin. This curve was translated into $\mathrm{g} / \mathrm{l} 00 \mathrm{~g}$ haemoglobin, so that this value could be obtained directly from the galvanometer reading on an Evelyn colorimeter. Blood was taken from the base of the tail, a lancet being used to make the incision.

Iron. Total iron was determined in the rations and the livers by the procedure of the Association of Official Agricultural Chemists (1950) with $\alpha \alpha^{\prime}$-dipyridyl. Dry ashing was used for the rations and wet ashing with sulphuric and perchloric acids for the livers.

Calcium. The procedure of the Association of Official Agricultural Chemists (1950) applicable to enriched, self-raising and phosphated flours was employed.

Phosphorus. The method of Berenblum \& Chain (1938) was used.

Test animals. Anaemic 35-day-old Wistar rats were used in these studies. They were obtained by the technique of Elvehjem \& Kemmerer (I931), except that the young were born and raised on wood shavings rather than a roll of cotton wool. From the time of weaning until the rats were put on test, whole-milk powder and water was their only food. From twelve to fifteen rats were placed on each diet and the values obtained for ten (five male and five female chosen at random) were used in all calculations, to simplify the statistical analysis. The rats were kept on test for a Io-week period. During this period the rats were weighed and haemoglobin values were determined weekly. At the end of the test period the rats were stunned by a blow on the head and their jugular veins were severed. After the rats had bled freely, the liver and heart were removed. These organs were weighed and stored at $-50^{\circ}$ until the analyses could be carried out.

\section{RESULTS}

The mean values from the assays of several lots of each diet are shown in Table 2.

The effect of increasing the iron and bone-meal content of the diet on food consumption, gain in body-weight, iron content of livers and heart weights for two experiments is shown in Fig. $\mathrm{I}$. The results obtained with the control diets, i.e. those containing no added iron or bone meal, used in Exps. I and 2, were averaged and are shown as one value in Fig. I. As might have been expected, when the iron content of the diet increased, there was a significant increase in both the total amount of diet consumed during the ro-week period and in the gain in body-weight. The presence of bone meal in the diet, on the other hand, had no significant effect on the amount of

* Alphacel is a non-nutritive cellulose supplied by Nutritional Biochemicals Incorporated, Cleveland, Ohio, U.S.A. 
Table 2. Amounts of $\mathrm{FeSO}_{4}$ and bone meal added to diets used in Exps. I and 2, and the iron, calcium and phosphorus contents of diets by analysis

\begin{tabular}{|c|c|c|c|c|c|c|c|}
\hline \multirow[b]{2}{*}{$\begin{array}{c}\text { Diet } \\
\text { no. }\end{array}$} & \multicolumn{2}{|c|}{ Additive } & \multicolumn{5}{|c|}{ Analytical results } \\
\hline & $\begin{array}{c}\mathrm{FeSO}_{4} \\
\text { (mg/lb. flour) }\end{array}$ & $\begin{array}{l}\text { Bone meal } \\
\text { (g/lb. flour) }\end{array}$ & $\begin{array}{c}\mathrm{Fe} \\
(\mathrm{mg} / \mathrm{I} 00 \mathrm{~g})\end{array}$ & $\begin{array}{c}\mathrm{Ca} \\
(\mathrm{mg} / \mathrm{I} 00 \mathrm{~g})\end{array}$ & $\underset{(\mathrm{mg} / 100 \mathrm{~g})}{\mathbf{P}}$ & $\begin{array}{l}\text { Ratio, } \\
\mathrm{Ca}: \mathrm{P}\end{array}$ & $\begin{array}{l}\text { Ratio, } \\
\mathrm{Ca}: \mathrm{Fe}\end{array}$ \\
\hline \multicolumn{8}{|c|}{ Experiment $I$} \\
\hline I & $\circ$ & $\circ$ & $2 \cdot 27$ & 310 & $16 \mathrm{I}$ & $I \cdot 9$ & I 37 \\
\hline 2 & 10 & $\circ$ & $2 \cdot 90$ & 328 & 163 & $2 \cdot 0$ & I I 3 \\
\hline 3 & 20 & $\circ$ & 3.40 & 345 & 170 & $2 \cdot 0$ & IOI \\
\hline 4 & 0 & $\mathrm{I} \cdot 5$ & $2 \cdot 41$ & 393 & 210 & $I \cdot 9$ & 163 \\
\hline 5 & 10 & $1 \cdot 5$ & 3.04 & 408 & 209 & $2 \cdot 0$ & 134 \\
\hline 6 & 20 & $1 \cdot 5$ & $3 \cdot 54$ & 383 & 210 & $\mathrm{I} \cdot 8$ & 108 \\
\hline 7 & 0 & $7 \cdot 5$ & $2 \cdot 34$ & 745 & 368 & $2 \cdot 0$ & 318 \\
\hline 8 & 10 & $7 \cdot 5$ & $3 \cdot 01$ & 708 & 367 & $1 \cdot 9$ & 235 \\
\hline 9 & 20 & $7 \cdot 5$ & 3.62 & 742 & 376 & $2 \cdot 0$ & 205 \\
\hline \multicolumn{8}{|c|}{ Experiment 2} \\
\hline 10 & 0 & $\circ$ & $2 \cdot 02$ & 309 & 152 & $2 \cdot 0$ & I 53 \\
\hline II & 40 & $\circ$ & 5.00 & 315 & I 55 & $2 \cdot 0$ & 63 \\
\hline 12 & 200 & $\circ$ & 15.07 & 297 & 151 & $2 \cdot 0$ & 20 \\
\hline 13 & 0 & $I \cdot 5$ & $2 \cdot 18$ & 408 & 207 & $2 \cdot 0$ & 187 \\
\hline$x_{4}$ & 40 & I. 5 & $5 \cdot 13$ & 437 & 209 & 2. I & 85 \\
\hline 15 & 200 & I. 5 & $14^{\circ} 5^{\circ}$ & 392 & I 97 & $2 \cdot 0$ & 27 \\
\hline 16 & 0 & $7 \cdot 5$ & $2 \cdot 29$ & 734 & 359 & $2 \cdot 0$ & $32 \mathrm{I}$ \\
\hline 17 & 40 & $7 \cdot 5$ & 5.07 & 734 & 347 & $2 \cdot I$ & 145 \\
\hline 18 & 200 & $7 \cdot 5$ & 14.90 & 734 & 368 & $2 \cdot 0$ & 49 \\
\hline
\end{tabular}

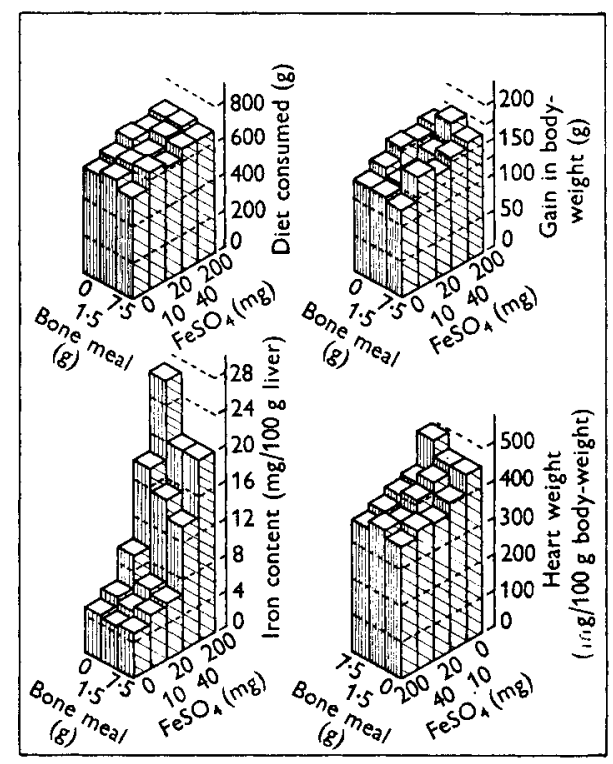

Fig. I. Effect of iron and bone-meal contents of diet on food consumption, body-weight, liver iron and heart weight of anaemic rats. Bone-meal $(\mathrm{g})$ and $\mathrm{FeSO}_{4}(\mathrm{mg})$ are shown as added per $\mathrm{lb}$. flour. 
food consumed or on the gain in weight of the rats. The levels of iron in the diets were enough to lead to significant increases in the iron contents of the livers. As may be seen from the analysis of variance in Table 3 , the presence of bone meal had no significant effect on the levels of iron in the livers in either Exp. I or 2. However, there is the suggestion in Exp. 2, and to a lesser extent in Exp. I, that with increasing amounts of bone meal there are decreasing amounts of iron to be found in the liver. In both experiments, sex had a significant effect on the iron content of the liver. This effect was more pronounced in Exp. 2 than in Exp. I. The difference between the two experiments was undoubtedly due to the larger amounts of iron fed in Exp. 2. In each experiment, both sexes were similarly affected by the presence of bone meal, hence the values for the iron content of the livers for the two sexes were combined and shown as one value in Fig. $\mathbf{I}$.

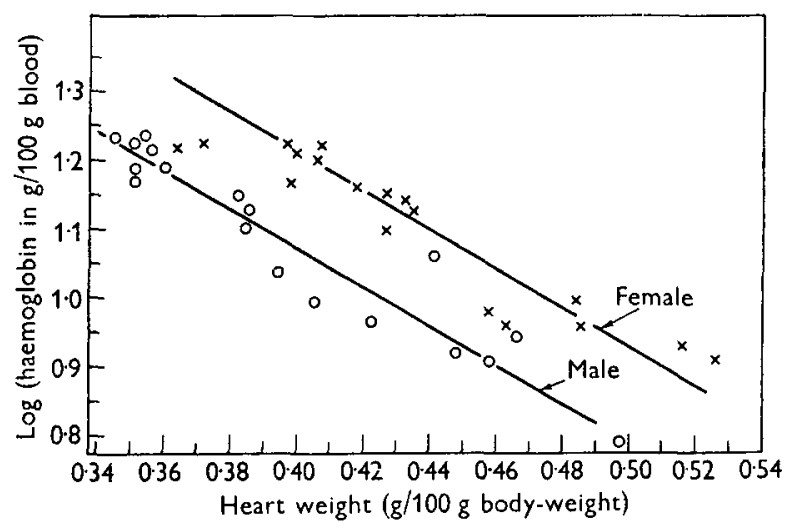

Fig. 2. Relationship between heart weight and haemoglobin level of rats.

It was found that, as the iron content of the diets increased, there was a significant decrease in the heart weights expressed in $\mathrm{g} / \mathrm{l} 00 \mathrm{~g}$ body-weight. The presence of bone meal in the diets, however, had no significant effect on heart weights. When the heart weights (expressed in $\mathrm{g} / \mathrm{I} 00 \mathrm{~g}$ body-weight) of all the rats used in Exps. I and 2 were plotted against the logarithms of the haemoglobin values, a straight-line relationship, as shown in Fig. 2, was found to exist. As the haemogolobin value increased, the weight of the heart decreased.

The rate at which haemoglobin was regenerated in the rats receiving varying amounts of added iron, but no added bone meal, is shown in Fig. 3. The values for iron shown in this figure are those found by analysis. As the iron content of the diet increased from 2.25 to $14.82 \mathrm{mg} / 100 \mathrm{~g}$ ration, there was a marked increase in the rate at which haemoglobin was regenerated. In the rats on the control diet containing no added iron, the haemoglobin values continued to fall after the rats were put on test and failed to reach the initial level until they had been on test for 5 weeks. In the rats receiving the highest level of iron in their diet, haemoglobin increased from $5^{\circ} 9$ to I $2.5 \mathrm{~g} / 100 \mathrm{ml}$. during the Ist week on test. From Fig. 3 it can be seen that all diets, except the one containing $2.25 \mathrm{mg}$ iron/roo g, though regenerating haemoglobin at 
different rates, have resulted in haemoglobin values, at the end of the ro-week period, in excess of $14 \mathrm{~g} / 100 \mathrm{ml}$. In Figs. 3 and 4 values shown for iron and calcium are the means for diets containing similar amounts of added iron or calcium, whereas in Table 2 the individual values are shown.

The effect on haemoglobin regeneration in the anaemic rat of the three levels of calcium superimposed upon each of the five levels of iron is shown in Fig. 4. The values

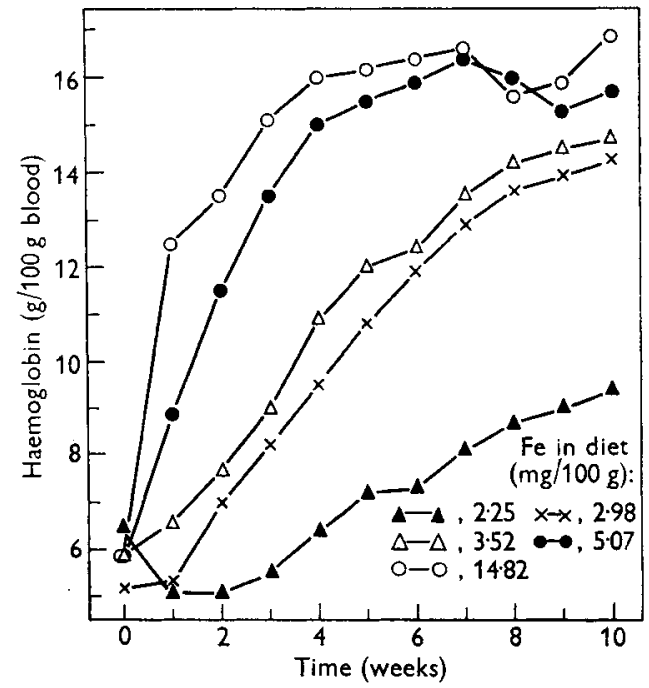

Fig. 3. Relationship between iron content of diet and haemoglobin level in rats.

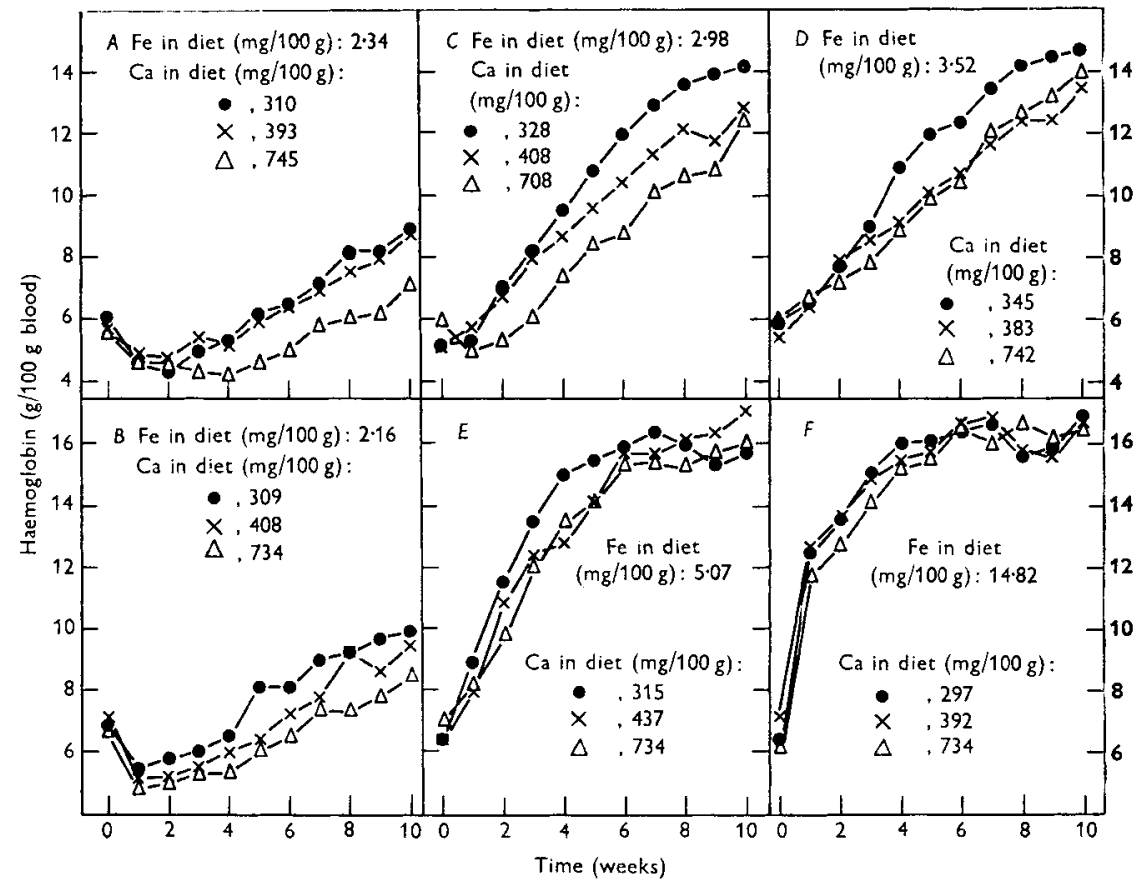

Fig. 4. Effect of iron and calcium content of the diet on haemoglobin regeneration in anaemic rats. 
for iron and calcium shown in this figure are those found by analysis. In Fig. $4 A$ is shown the effect of the three levels of calcium on haemoglobin regeneration on diets containing $2.34 \mathrm{mg}$ iron/100 $\mathrm{g}$ diet as used in Exp. I. The increase in the calcium content from 3 Io to $393 \mathrm{mg} / 100 \mathrm{~g}$ did not result in a significant decrease in the rate at which these rats were able to regenerate haemoglobin. However, the rats receiving the diet containing $745 \mathrm{mg}$ calcium from the $3^{\text {rd }}$ to the Ioth (excluding the $4^{\text {th }}$ and 7 th) weeks had haemoglobin values significantly less than those of the rats receiving the diets containing $393 \mathrm{mg}$ calcium. When the $745 \mathrm{mg}$ level of calcium in the diet was compared with the $310 \mathrm{mg}$ level, the higher level of calcium was found to result in a significantly lower haemoglobin level at the 5 th, 6th, 8th 9 th and Ioth weeks. Similar diets were used in Exp. 2 and the results are shown in Fig. $4 B$. In this experiment the diet containing $408 \mathrm{mg}$ calcium resulted in lower haemoglobin values at the

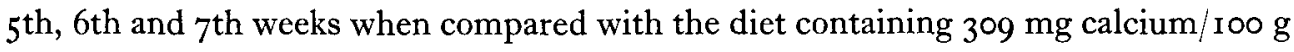
diet. The diet containing $734 \mathrm{mg}$ calcium resulted in lower haemoglobin levels from the $4^{\text {th }}$ to the Ioth weeks. From the results shown in Fig. $4^{A}$ and ${ }_{4} B$ it would appear that when relatively large amounts of bone meal are added to a diet containing small amounts of iron, significant retardation in the rate of haemoglobin regeneration results.

In Fig. ${ }_{4} C$ the effect of adding three levels of bone meal to diets containing $2.98 \mathrm{mg}$ iron/100 $\mathrm{g}$ (10 $\mathrm{mg} \mathrm{FeSO}_{4} / \mathrm{lb}$. flour) is shown. At only one point (the $9^{\text {th }}$ week) was there any significant difference between the 328 and $408 \mathrm{mg}$ level of calcium. However, the diet containing $708 \mathrm{mg}$ calcium did result in significantly lower haemoglobin values from the and to the roth week, in spite of the fact that the rats with the high intake of calcium consumed slightly more diet and hence more iron than did the controls.

In the experiments presented in Fig. ${ }_{4} D$ the iron content of the diets was increased to $3.52 \mathrm{mg} / \mathrm{roO} \mathrm{g} \mathrm{(20} \mathrm{mg} \mathrm{FeSO} / \mathrm{lb}$. flour). At this level of iron, the levels of calcium, 345,383 or $742 \mathrm{mg} / \mathrm{roo} \mathrm{g}$ diet, had no significant effect on haemoglobin regeneration except at the 9 th week in the comparison between the 345 and $383 \mathrm{mg}$ level of calcium. Similarly, as shown in Fig. ${ }_{4} E$ and ${ }_{4} F$, at iron levels of 5.07 and $14.82 \mathrm{mg} / 100 \mathrm{~g} \mathrm{diet}$ (40 and $200 \mathrm{mg} \mathrm{FeSO}_{4} / \mathrm{lb}$. flour) the three levels of bone meal had no significant effect on the haemoglobin values at any time during the test except with the $5.07 \mathrm{mg}$ level of iron, when there were points of significance at the 2 nd and $4^{\text {th }}$ weeks.

\section{DISCUSSION}

It is a generally accepted fact that iron is metabolized by the body in a manner differing from that of most other elements, which appear to be absorbed freely, the excess being excreted. Iron once absorbed is largely retained. Some mechanism for the control of iron absorption must exist: it appears to be localized in the gastro-intestinal mucosa and has been described by Granick (1946). He has suggested that this regulatory mechanism is a function of the ferritin content of the mucosa. When the cell is physiologically saturated with ferrous iron, it is assumed that no further iron is absorbed from the tract. This condition has been referred to as 'mucosal block'. Only when the ferritin iron has decreased to a point at which the mucosal cells are no longer physiologically saturated with ferrous iron will more iron be absorbed. Reports 
in the literature appear to indicate that the mucosal block is ineffective during deficiency of pyridoxine (Gubler, Cartwright \& Wintrobe, r949) or protein (Hallgren, I953) and that it can be overcome by feeding large amounts of iron (Kinney, Hegsted \& Finch, 1949). Gubler et al. (1949) showed that the absorption of iron is increased during pyridoxine deficiency. Since synthesis of haemoglobin is retarded during pyridoxine deficiency, it would be expected that the need of the body for iron would be reduced. In spite of this Gubler et al. (1949) have shown that iron was absorbed to such an extent that the total body iron actually increased. Hallgren (1953) has shown that, as the protein content of the diet decreases from 9 to $2.25 \%$, the iron content of the liver, spleen and carcass increases. During iron-deficiency anaemia, the mucosal cells are presumably not saturated with iron, the musocal block is not operating and iron is freely absorbed.

Under the conditions of the present study, it was found that the presence of large amounts of bone meal added to a bread diet relatively low in iron interfered with the utilization of iron, as reflected by haemoglobin regeneration, in spite of the anaemic condition of the animals and their great need for iron. Though the rats used in our studies were markedly anaemic, so that the mucosal block should not have been operating, the fact that in the presence of large amounts of bone meal the rats regenerated haemoglobin very slowly suggested either that the mucosal block was operating, or that the iron by some means had been rendered unavailable. When the bone-meal content of the diet was such that the amount of calcium present had reached a value near $740 \mathrm{mg} / \mathrm{ro0} \mathrm{g}$ diet and the iron content of the diet was less than $3 \mathrm{mg} / \mathrm{ro0} \mathrm{g}$, there appeared to be an adverse effect on the utilization of iron as reflected by haemoglobin regeneration. Thus, when the calcium: iron ratio was approximately 250 , the amount of iron absorbed appeared to be reduced. If, however, the iron content of the diet was increased to $3.5 \mathrm{mg} / \mathrm{r} 00 \mathrm{~g}$, with the calcium content remaining at $740 \mathrm{mg} / \mathrm{ro0} \mathrm{g}$, then the presence of the bone meal had no significant effect on haemoglobin regeneration. It is appreciated, however, that the calcium: iron ratio is only one of many factors that may affect utilization of iron. Kletzien (1940), finding that calcium exerted an adverse effect on iron assimilation, concluded that it might have been a result of a disturbance in the normal concentration of the common inorganic ions in the principal absorptive portions of the digestive tract. Greig (1954) found that $\mathrm{CaCO}_{3}$ interferes with the utilization of iron in mice and concluded that the individual effects of both $\mathrm{CaCO}_{3}$ and iron supplements were strong and in opposite directions and that there was no apparent interaction between them. Greig stated, further, that the anaemia caused by the $\mathrm{CaCO}_{3}$ was not the result of an induced deficiency of iron, but that $\mathrm{CaCO}_{3}$ produced anaemia through some interference with the assimilation or utilization of iron.

It should be noted that at the lowest level of iron, the presence of bone meal had, in these studies, no effect on the iron content of the liver, whereas at the two highest levels of iron the presence of bone meal resulted in a significant decrease in the iron content of the livers of the female rats. However, as shown in Table 3 , there was no overall effect of the addition of bone meal. The fact that bone meal had no effect on the haemoglobin values at these high levels of iron suggests that iron for haemoglobin 
formation has priority over iron for liver storage. Kletzien (1940) reported that I and $3 \%$ of $\mathrm{CaCO}_{3}$ in the diet resulted in liver iron values of 57 and $28 \%$, respectively, of the controls.

Table 3. Analysis of variance of the iron content of livers of rats in Exps. I and 2

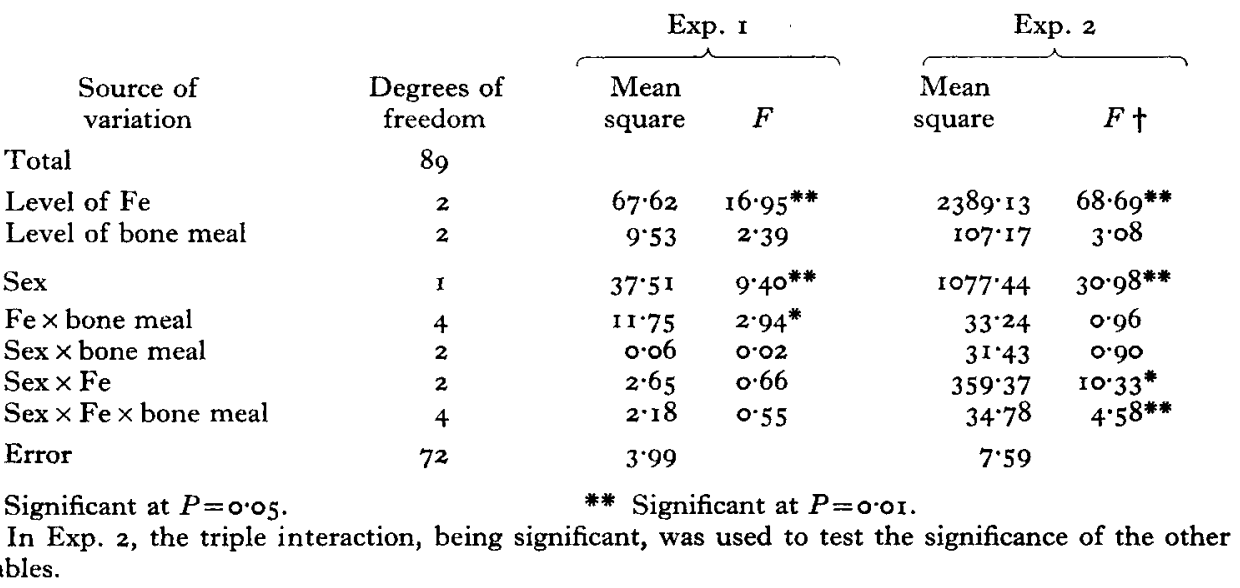

It was also noted that the presence of bone meal had no significant effect at any level of iron on the heart weights of the rats in our experiments, though in a subsequent study an effect was observed. Greig (1952) has shown that both absolutely and relatively to body-weight the heart weights of weanling mice were significantly increased by the presence of calcium carbonate in the diet of the mothers $(0.55$ and $1.1 \%$ calcium in the diet). The high calcium ( $\mathrm{I} \cdot \mathrm{I} \%$ of diet) also caused a significant increase in the absolute and relative heart weights of the mothers.

It should be pointed out here that the level of bone meal of $I \cdot 5 \mathrm{~g} / \mathrm{lb}$. flour is approximately equivalent to the amount permitted in enriched flour in Canada. The Canadian Food and Drug Regulations (Office Consolidation of the Food and Drugs Act and of the Food and Drug Regulations, I954) for enriched flour, state that it may contain added 'calcium carbonate or edible bone meal in an amount that will provide in one pound of enriched flour not less than 500 milligrams and not more than 650 milligrams of calcium'. Thus the results of the present study suggest that, if bone meal is added in an amount approximating to the level permitted for enrichment purposes, the utilization of iron by the anaemic rats is not interfered with. However, when the amount of bone meal is increased to five times that level, and the iron content of the diet is relatively low, then there is clear-cut interference with the uptake of iron under the conditions of this study.

\section{SUMMARY}

I. Bread diets, supplemented with three levels of bone meal and five levels of ferrous sulphate, have been fed ad lib. to anaemic rats for a period of ro weeks. Ten rats, five male and five female, were used in each group. The diets were found to contain on the average $2.34,2.98$ and $3.52 \mathrm{mg}$ iron/100 $\mathrm{g}$ in Exp. I, and $2 \cdot 16,5.07$ 
and $14.82 \mathrm{mg}$ iron/100 $\mathrm{g}$ in Exp. 2, and the mean calcium content for both experiments was 317,403 and $733 \mathrm{mg} / \mathrm{loo} \mathrm{g}$.

2. It has been found that at the $2 \cdot 16,2 \cdot 34$ and $2 \cdot 98 \mathrm{mg}$ levels of iron the presence of large amounts of bone meal had no effect on food consumption, but did significantly retard haemoglobin regeneration. At the $3.52,5.07$ and $14.82 \mathrm{mg}$ levels of iron, bone meal did not affect haemoglobin levels to a significant degree.

3. The presence of bone meal did not result in an overall significant decrease in liver iron content.

4. As the iron content of the diet increased, the heart weights decreased, but the presence of the bone meal had no significant effect on the heart weights.

5. When bone meal was added to the flour in an amount approximating to that in enriched flour, its presence had no adverse effect on iron utilization in anaemic rats.

The authors wish to express their thanks to Mr E. R. W. Gregory for supplying the experimental animals, to Miss Rita Seguin and Mrs Odette Milstone for their valuable technical assistance in the preparation and analyses of diets and the care of the experimental animals, and to Mr Robert Hoare for determining the iron contents of the livers and for assistance in the calculations.

\section{REFERENCES}

Anderson, H. D., McDonough, K. B. \& Elvehjem, C. A. (1940). F. Lab. clin. Med. $25,464$.

Association of Official Agricultural Chemists (1950). Official and Tentative Methods of Analysis, 7 th ed. Washington: Association of Official Agricultural Chemists.

Berenblum, I. \& Chain, E. (1938). Biochem. F. 32, 295.

Davidson, L. S. P., Fullerton, H. W., Howie, J. W., Croll, J. M., Orr, J. B. \& Godden, W. (r933). Brit. med. F. i, 685 .

Day, H. G. \& Stein, H. J. (1938). F. Nutr. 16, 525 .

Dell'Aquila, M. D. \& Bini, G. (1953). Rif. med. 67, 1073.

Elvehjem, C. A. \& Kemmerer, A. R. (1931). F. biol. Chem. 93, I89.

Freeman, S. \& Ivy, A. C. (1942). Amer. F. Physiol. r37, 706.

Granick, S. (1946). F. biol. chem. 164, 737.

Greig, W. A. (1952). Brit. F. Nutr. 6, 280.

Greig, W. A. (1954). Proc. Nutr. Soc. 13, iii.

Gubler, C. J. (1956). Science, 123, 87.

Gubler, C. J., Cartwright, G. E. \& Wintrobe, M. M. (1949). F. biol. Chem. 178, 989.

Hallgren, B. (1953). Acta Soc. Med. upsalien. 59, 79.

Hegsted, D. M., Finch C. A. \& Kinney, T. D. (1949). F. $\exp$. Med. 90, 147.

Kinney, T. D., Hegsted, D. M. \& Finch, C. A. (1949). F. exp. Med. 90, I37.

Kletzien, S. W. (1940). F. Nutr. 19, 187.

Office Consolidation of the Food and Drugs Act and of the Food and Drug Regulations (1954). Ottawa, Canada: Queen's Printer.

Orten, J. M., Smith, A. H. \& Mendel, L. B. (1936). F. Nutr. 12, 373.

Perosa, L. \& Raccuglia, G. (195 I). Boll. Soc. ital. Biol. sper. 27, 1588.

Pett, L. B. (1952). Fed. Proc. I1, 453 .

Pharmacopoeia of the United States of America, Fourteenth Revision (x950). Easton, Pa., U.S.A.: Mack Publishing Company.

Rimington, C. (1942). Brit. med. F. i, 177.

Sherman, H. C. (1907). Bull. U.S. Off. Exp. Sta. no. 185.

von Wendt, G. (1905). Skand. Arch. Physiol. r7, 211.

Widdowson, E. M. \& McCance, R. A. (1942). Lancet, 242, 588. 